\title{
Bachtin, autor-iteten og modernismen
}

Det er blevet moderne at afsløre modstridende stemmer hos flerstemmighedens teoretiker Michail Bachtin. Det er unægteligt en nærliggende metaoperation. Og allerede under den første vestlige Bachtin-reception i slutningen af 1960'erne og begyndelsen af 1970'erne ${ }^{1}$ stod det klart for de fleste, at der dels var forskellige modstridende tendenser i den omarbejdede Dostojevskij-bog, dels tydelige forskelle i stil som i indhold mellem denne bog som helhed og Rabelais-bogen. Med den anden Bachtin-reception i begyndelsen af 1980'erne og den tredje fra omkring 1990 er det blevet stadigt klarere, at mangfoldigheden - mængden og arten af modsætninger - i Bachtins værk er meget større end tidligere antaget. Ikke mindst fordi flere nye faser blev tilgængelige. Den anden reception introducerede og fokuserede ${ }^{2}$ på de romanteoretiske essays mellem førsteudgaverne af Dostojevskij- og Rabelais-bøgerne. I den tredje reception kom (mindst) to nye faser i forgrunden: - de filosofiske og litteraturteoretiske ungdomsværker fra 1919 og frem til Dostojevskij-bogen i 1929; de sprogteoretiske og filosofiske alderdomsværker fra lige før og især tiåret efter omarbejdelsen af de to store monografier. Hermed er det blevet umuligt at overse de indre modsætninger. Samtidig er der blevet bedre baggrund for på en ny måde og et trinhøjere niveau at se en sammenhæng. Den igangværende fjerde reception med udgivelsen af de samlede værker på russisk og det forventelige væld af oversættelser (hvortil Nina Møller Andersen bidrager i dette $K \& K$-nummer) vil utvivlsomt nuancere billedet betydeligt, men næppe ændre det afgørende med tilkomsten af nye faser o.l. Det vil imidlertid snart vise sig.

En forståelse af Bachtins værk og dermed sammenhængende estimering af dets brugbarhed må tage udgangspunkt i dets indre modsætninger. Først på baggrund af et nogenlunde korrekt historisk og kritisk billede af forfatterskabets udviklingsdynamik og mangfoldighed kan vi vurdere de enkelte bidrags styrke og begrænsninger samt på ny stille spørgsmål om sammenhængen.

Forudsætningen er selvfølgelig et forsvarligt billede. Paradoksalt nok er de senere års jagt på modsætninger i Bachtins værk ofte styret af en stærkt reduktionistisk holdning. Værket som helhed eller dele af det klassificeres/kas- 
seres med fagligt bornerte udgangspunkter. Den brede interesse for Bachtin langt uden for det litterære og sproglige felt, han altid forholder sig til, har som bivirkning haft fagligt $\mathrm{u}(\mathrm{den})$ forstående Bachtin-studier. En anden følgevirkning af Bachtins status som varmt stof er indlæg, der tyder på et utilstrækkeligt kendskab til de på det pågældende tidspunkt tilgængelige dele af forfatterskabet. Bachtin er blevet et pejlemærke i teori- og kulturdebatten. Hans popularitet (som også kan skride ud i idolisering) udløser derfor ideologisk idiosynkratiske reaktioner i form af hele eller delvise afvisninger af hans værk. Nogle afviser det tidlige forfatterskab ud fra en modvilje mod enten nykantianisme eller fænomenologi eller begge dele. Mange affejer Dostojevskij-bogens polyfonibegreb som spekulativt og uhåndterligt. Endnu flere tager afstand fra Rabelais-bogen og karnevalsbegrebet ud fra 'cultural reaganism' eller generel afsky for alt, hvad der svagt minder om 1970'erne, hvad denne bog åbenbart menes at gøre. Endelig afviser nogle det hele ud fra en radikal afskrivning af alle emancipatoriske tendenser i det 20. århundredes humanistiske tænkning, som Bachtins værk restløst ses at repræsentere - uanset dets miserable sammenhængsløshed. Jeg vil eksemplificere nogle af disse tendenser ved polemiske strejftog i Gábor Bezeczkys og Galin Tihanovs Bachtin-opfattelser.

Mit positive hovedsigte er, at jeg med udgangspunkt i autorbegrebets metamorfoser gennem forfatterskabet vil søge at bidrage til et præcisere billede af dets indre modsætninger. Herigennem vil jeg skitsere en revurdering af Bachtins forhold til modernismen og hans placering af Dostojevskijs polyfone roman i denne sammenhæng. Et afgørende moment i denne litteraturhistoriske profilering er en sammenligning mellem Lukács og Bachtin, en alternativ fremstilling af deres skiftende, men i hovedsagen altid polære positioner.

\section{Modsigelser. Anti-modernisme?}

Gábor Bezeczkys artikel »Contending Voices in Bakhtin « ${ }^{3}$ er interessant og repræsentativ i flere henseender. Den slår overbevisende ned på flere modsigelser i og omkring Dostojevskij-bogens polyfonibegreb. Det er modsigelser, jeg selv har hæftet mig ved, de tre første (af de nedenfor anførte) allerede i min introduktionsartikel »Dialogen og den tragiske farce - Michail Bachtins teoretiske arbejde. $\aleph^{4}$ Min umiddelbare reaktion var tilslutning til de fleste af Bezeczkys synspunkter. Og jeg er stadig enig i følgende:

- Der er manifeste og latente forskydninger mellem de bevarede dele af 1929-bogen (der især præger 2. og 3. kapitel) og de nye elementer i 1963-udgaven (især 4. og 5. kapitel). 
- Dostojevskij-bogens personlighedsbegreb - forholdet mellem person, identitet, bevidsthed og stemme - er langtfra krystalklart.

- De fremstillede personers art og grad af uafhængighed af forfatteren er et kompliceret spørgsmål, der lægger op til videre fortolkning og afklaring.

- Der er en tydelig forskel mellem Dostojevskij-bogens billede af litteraturens - specielt romanens - nyere historie og det tilsvarende billede i 1934-35-essayet »Ordet i romanen«. Ifølge den første (3. kapitel) præger monologismen gennemgribende vor tid, ifølge »Ordet i romanen« er den dialogiske heteroglossia-tendens den dominerende i romanens nyere udvikling.

På baggrund af flere gennemlæsninger har jeg dog fået stof til alvorlige indvendinger. Bezeczkys artikel er præget af en enten-eller-tænkning, der ligger meget langt fra Bachtins tankeform, ja, blokerer for adgang til den. Hans problematiseringer har form af enkle dilemmaer. Samtidighed af forskellige analyseniveauer og komplementaritet i enhver udgave er ham åbenbart fremmed. Han er tydeligvis ret begrænset og overfladisk orienteret i Bachtins værk. Hans implicitte alternativer forekommer mig litteraturteoretisk problematiske.

I relation til helten og bevidstheden nøjes Bezeczky med at trække det dilemma op, hvorvidt en person, der betegnes som en karikatur på en anden, kan være en ligeberettiget bevidsthed? Han går uden om dobbeltgænger-problematikken og skraber kun i overfladen af det interessante problem, han har taget op. Tilsyneladende med alment sigte hævder han: »Bachtin viede en hel del opmærksomhed til samtidighed, men så bort fra de tidslige aspekter af at være "på tærskelen. « ${ }^{5}$ Det er imidlertid en absurd påstand, når man tænker på metamorfose-temaet i Dostojevskij-bogens 4. kapitel, og ikke mindre i relation til det essay, der primært handler om litteraturens »tidslige aspekter « og introducerer det samme tema, nemlig »Kronotopen «.

Bezeczky opsætter et absolut dilemma mellem Bachtins dialogiske sandhedsbegreb og det synspunkt, at objektive forhold i perioden (den moderne heterogene mangfoldighed, der satte sig igennem med kapitalismen) udgjorde forudsætninger for skabelsen af den polyfone roman. Bezeczkys synspunkt er præget af en voldsom aversion mod enhver historisk-epokal synsvinkel på dialogismen. Men Bachtin er næsten altid også historisk-epokalt orienteret.

Bezeczkys karakteristikker og dilemmaer hviler på et temmelig smalt grundlag, nemlig udelukkende på en modstilling af Dostojevskij-bogen (i begge versioner) og »Ordet i romanen «. Sidstnævnte idealiseres, men på baggrund af en forenklet, ja, misvisende fremstilling. Stort set ignoreres alle andre værker. Resultatet er et mere til- end afslørende billede af Bachtins opfattelser. 
Synspunkter som Bezeczkys med hovedsagelig reverens til romanessayene, i særdeleshed »Ordet i romanen «, repræsenterer en udbredt tendens i de senere års anglo-amerikanske Bachtin-reception. I samme forbindelse er det almindeligt at møde en beklagelse af Bachtins manglende orientering i moderne europæisk litteratur og hans konservative litteratursmag, der eventuelt anses for at stå i kontrast til de avancerede implikationer i hans teorier. Også i den bulgarsk-franske Tzvetan Todorovs biografisk orienterede foredrag om Roman Jakobson og Michail Bachtin på Københavns Universitet i efteråret 1996 blev en lignende opfattelse hævdet.

En af kilderne til denne opfattelse er ganske givet nogle bemærkninger i Rabelais-bogen. I den indledende »Problemstilling « hævder Bachtin, at den groteske litterære tradition oplever »en ny og mægtig renæssance « i dette århundrede. Han udskiller to hovedlinjer: Modernistisk groteske (Alfred Jarry, surrealisterne, ekspressionisterne etc.), der mere eller mindre går tilbage til den romantiske groteskes traditioner, og for det andet:

»den realistiske groteske (Thomas Mann, Bertolt Brecht, Pablo Neruda og andre); denne linje er forbundet med den groteske realismes og den folkelige kulturs traditioner, og genspejler undertiden ligefrem en direkte indflydelse fra karnevallets former (Pablo Neruda). $\ll^{6}$

For en engageret modernisme-fan er sådan en passage jo ikke comme il faut. Bachtin kan meget vel have foretrukket Mann, Brecht og Neruda - der på den anden side næppe kan karakteriseres som helt normale husholdningsrealister frem for Jarry. Det er i hvert fald indlysende, at eksistentialisten Bachtin har været ret irriteret på en bestemt selvhøjtidelig, selvsmagende 50'er-eksistentialistisk fims omkring modernismen. Det viser den efterfølgende polemik, Rabelais-bogens skarpeste, mod Wolfgang Kaysers Das Groteske in Malerei und Dichtung fra 1957. Der er næppe i dette tilfælde tale om taktiske hensyn. Men man må dog også tage højde for, hvad Bachtin mente at kunne tillade sig i Sovjetunionen i midten af 1960'erne, især med tanke på eftervirkningerne af den stalinistiske undertrykkelse og censur med de bekendte uhyggelige konsekvenser for Bachtin selv.

Under alle omstændigheder er billedet af Bachtins forhold til modernismen mere kompliceret end som så. Bachtin har haft en egen akut bevidsthed om og konstant arbejdet med - de kulturelle og litterære metamorfoser, som er udsprunget af moderniteten og manifesteret i modernismen bredt forstået. Hans teorier er udsprunget af en sådan bevidsthed, som han dels tematiserer indirekte, dvs. tilbageskudt til tidligere brydningstider, dels teoretiserer direkte 
over. Med autorbegrebet som ledetråd vil jeg prøve at fremdrage nogle af denne modernitetsbevidstheds mere direkte udtryk.

\section{Forfatteren som guddommelig skaber og autor-itetens krise}

Bachtins tidligste større værk Mod en handlingens filosofi er fænomenologisk og moralfilosofisk. ${ }^{7}$ Det bruger mest krudt på at analysere det forhold mellem jeg, den anden og jeg-for-den-anden, som det hævder, at alle værdier grupperer sig om. Bachtin skildrer ikke mindst forholdet ved hjælp af en blikkets fanomenologi, hvor han på mange måder foregriber den unge Sartre, skønt ud fra et mere håbefuldt billede af mellemmenneskelige forhold.

Blikkets fænomenologi er særlig klart udformet i Bachtins næste og større filosofisk-litterære manuskript, »Forfatter og helt i æstetisk aktivitet « fra omkring 1924. Med (bevidst) slægtskab til relativitetsteorien tager Bachtin udgangspunkt i, at hver enkelt indtager en enestående plads i rummet (og tiden). Vi kan derfor se adskilligt hos hinanden, f.eks. helt banalt i det ydre, som vi ikke kan se hos os selv. Bachtin kalder det syns-overskud:

»Dette bestandige overskud i det, jeg ser, ved og besidder i forhold til ethvert andet menneske, er funderet i det enestående og uerstattelige ved mit sted i verden. For kun jeg - jeg-ene-og-alene - optager under givne omstændigheder dette særlige sted på dette særlige tidspunkt; alle andre mennesker er placeret uden for mig. $\ll^{8}$

Et solidt argument for individualismen, men samtidig for medmenneskets uundværlighed. Ved sit overskud er den anden uundværlig til at komplettere mig. En oplevelse af vores ydre får vi især via andres reaktioner på det. Sproget får vi ikke mindst gennem moderens kærlige intonation samt videre gennem dialogen i det hele taget.

Det er slående, hvor mange af Bachtins senere teoretiske knudepunkter, der foregribes af denne fænomenologiske korrelation af kroppe i rum, af blikretninger, af dialektikken mellem at se og ses. Kropsligheden. Rum og tid, kronotop-begrebet. Relativitet, komplementaritet. Skabertropen, vi skaber hinanden ved vores overskud i forhold til hinanden. Og naturligvis dialogen, den dialogiske interaktion mellem jeg og den anden som det basale i væren-sombegivenhed - og udgangspunkt for humaniora.

Synsvinkelkomplementariteten er sammenknyttet med skabertropen: 
»Ifølge denne metafor er forfatternes forhold til deres karakterer beslægtet med Guds forhold til mennesker. Når alt kommer til alt, er dette et skabernes forhold til de skabte, hvilket er årsagen til, at det så ofte beskrives i termer, der er overtaget fra religion. «9

Ifølge Clark og Holquist er skabertropen ligefrem en mestertrope i Bachtins værk:

»Forfatterskabs-handlingen, der tages op i Arkitektonikken [Bachtins egen arbejdstitel for det samlede projekt i de uudgivne ungdomsværker], er mestertropen i hele Bachtins værk. Forfatteres møde med de helte, de væver ind i deres teksters verden, viser sig at være en vellykket form til at bringe sammenhæng og mønster i alle Bachtins andre kategorier. $\ll^{10}$

På denne baggrund søger Bachtin at bestemme forholdet mellem autor og helt i romanen. Dels i en form for normativ poetik. Dels deskriptivt i relation til særlige subgenrer af romanen, i forhold til bestemte forfatteres orientering og relateret til specifikke epokale brydninger. Hovedidealet er, at forfatteren skal kunne afrunde, færdiggøre, finalisere den fremstillede person. Det forudsætter en passende distance: autor må ikke fortabe sig i sin helt, men heller ikke komme på så stor afstand, at indlevelse er umulig. Den vellykkede autor-heltrelation kommer til udtryk i en vekselvirkning mellem 'det fremmede blik' og 'den sympatetiske sam-følelse'.

Med det fremmede bliks strategi sætter autor sig i Guds sted, 'uden for' verden: »Kunstnerens guddommelighed består i hans delagtighed i den yderste udenforståenhed « ( $A A A$, s. 191). Ved denne distancering afsløres heltens ydre omrids; og desuden verdens sprækker, kløfter, hulheder, der åbnes for kritikken, satiren, den guddommelige komik.

Komplementært udfolder identificeringens bevægelse sig: indlevelsens strategi, den skabende overvindelse af - ofte kunstige - afstande. Det er inkarnationen, skaberens nedstigning fra guddommelig fjernhed for at få krop og indtage en position i menneskenes verden:

»Enhver vurdering er en handling, hvori man indtager en individuel stilling i væren; selv Gud måtte inkarnere sig for at skænke nåde, for at lide og for at tilgive - måtte så at sige stige ned fra retfærdighedens abstrakte standpunkt.« (AAA, s. 129)

Gud-skaberen sætter sig i menneskets sted. 
En total identificering med en anden ville imidlertid (dersom den i det hele taget er mulig) være en fortabelse i denne anden. Det delvise i sammensmeltningen må understreges. Indlevelse er et møde mellem to bevidstheder. Det indlevende jeg kan se sider ved den anden, som er utilgængelige for denne selv, og kan netop derved komplettere den anden. Om indlevelsens æstetiske funktion siger Bachtin:

»Jeg må føle eller projicere mig ind i dette andet menneske, se dets verden aksiologisk indefra, som det ser sin verden; jeg må sætte mig selv i dets sted og så, efter at være vendt tilbage til mit eget sted, »udfylde « dets horisont ved hjælp af det syns-overskud, der åbner sig ud fra dette, mit eget, sted uden for det.«(AAA, s. 25)

Den kærlige afrunding af den fremstillede person - det er autor-itetens mulighed og forpligtelse. Forfatteren er helt i friheden, mens helten er underlagt den skabende rytmes æstetiske nødvendighed:

»Skaberen er fri og aktiv, mens den skabte er ufri og passiv. Sikkert nok er ufriheden, nødvendigheden i et liv, der skabes af rytme, ikke en grusom nødvendighed, ikke en nødvendighed, der er ligegyldig over for værdi (kognitiv nødvendighed); det er snarere en nødvendighed, der skænkes som gave, skænkes af kærlighed: det er en smuk nødvendighed.«(AAA, s.119)

Det interessante er, at dette indfølte forsvar for en klassisk narrativ æstetik munder ud i Bachtins konstatering af, at forfatter-autoriteten historisk set er i krise. Og en af hovedskurkene i denne æstetiske værdiopløsning er Dostojevskij - af omtrent de samme grunde, som Bachtin siden fremførte til fordel for hans heltestatus. En forfatter som Dostojevskij bekymrer sig ikke længere om at skildre den fremstillede persons ydre og placere ham eller hende i sit naturlige miljø. Hvad mere er:

»Dialogerne mellem hele mennesker $[\ldots]$ begynder at degenerere til selvoptagne disputationer, hvis værdicenter ligger i de debatterede problemer. Og endelig forenes de fuldendende momenter ikke: forfatteren mangler al enheds-fremtræden - er enten en spredt fremtræden eller en konventionel maske. Denne type inkluderer næsten alle Dostojevskijs helte, nogle af Tolstojs helte (Pierre, Levin), Kierkegaard, Stendhal $[\ldots] \ll(A A A$, s.19f.) 
Knap 200 sider senere rekapitulerer og ekspanderer han disse litteraturhistoriske betragtninger i afsnittet »Forfatteren som problem«, der indgår i kapitlet »Tradition og stil«. Han skildrer her forfatter-skabets, forfatter-rollens eller autor-itetens krise (»The crisis of authorship«), der kan tage forskellige retninger. Én af dem er at:

»Selve forfatterens udenforstående position rystes og regnes ikke længere for væsentlig: man bestrider forfatterens ret til at være placeret uden for det levede liv og fuldende det. Alle stabile overskridende former begynder at falde fra hinanden (først af alt i prosa - fra Dostojevskij til Belyj; forfatterskabets krise er altid af mindre betydning i lyrik - Annenskij osv.).«(AAA, s. 203)

Den manglende vilje til at påtage sig forfatterrollens byrde ser den unge Bachtin som udtryk for en angst for ansvar, der æstetisk ytrer sig som en angst for grcenser. Men, hævder Bachtin: »Æstetisk kultur er en grænsernes kultur « (AAA, s. 203).

\section{Bachtins kopernikanske revolution}

Mellem dette klassiske æstetiske standpunkt og positionen i såvel Dostojevskij-bogen som 30'er-essayene foreligger der hos Bachtin en kopernikansk revolution i stil med den, han skildrede hos Dostojevskij. Et hovedanliggende $\mathrm{i}$ indkredsningen af Dostojevskijs polyfoni er at karakterisere den nye forfatterposition. Specielt under behandlingen af det nye forhold til helten i $2 . \operatorname{og} 3$. kapitel, men også under de følgende kapitlers genre- og sprogsynsvinkler. Det er nu en afgørende kvalitet ved forfatteren, at han ikke søger at afgrænse og finalisere, og en afgørende kvalitet ved helten, at han ikke tåler at lade sig objektivere. Helten karakteriseres af en altopslugende selvbevidsthed, ufuldbyrdet, åben og ubestemt. Dette kræver netop en ny autorposition: »Selvbevidstheden som den kunstneriske dominant ved fremstillingen af helten forudsætter også en radikalt ny forfatterposition i forhold til det skildrede menneske. ${ }^{11}$

Hovedpersonerne i Dostojevskijs tidlige værker hævder jo polemisk deres integritet mod 'det fremmede blik', mod andres mere eller mindre imaginære vurderinger. Bachtin fremdrager ikke mindst Devusjkin i Arme mennesker med hans protest mod Gogols finaliserende, tingsliggørende billede af den lille kontorist. Han føler sig personligt forulempet, forudberegnet, opmålt, defineret, »set ude fra«, »fuldbyrdet «. Bachtin fortolker det således: »Den alvorlige, dybere betydning af dette oprør kan man udtrykke på følgende måde: man må 
ikke forvandle et levende menneske til et stumt objekt for en viden, som fuldbyrder det i dets fravær« (Dost, s.65f.). Bemærk anvendelsen af de selvsamme nøglebegreber som i »Forfatter og helt i æstetisk aktivitet « (hvad jo ikke kunne bemærkes, før dette væsentlige værk var blevet udgivet!) - men nu med omvendt fortegn. Denne ejendommelige blanding af kontinuitet og brud kan vel at mærke iagttages overalt i Dostojevskij-bogen. Samtidig med at Bachtin åbent skildrer omvæltningen i forholdet mellem Gogol og Dostojevskij, gennemfører han i det skjulte selv en kopernikansk revolution i forhold til sin egen tidligere position $\mathrm{i} »$ Forfatter og helt $\mathrm{i}$ æstetisk aktivitet«.

I Bachtins 'forklaring' på Dostojevskijs skabelse af den polyfone roman indgår en flerhed af fænomener, der befinder sig på forskellige planer. Efter behag kan man kalde dette »contending voices « eller et avanceret fors $\emptyset \mathrm{g}$ på at tænke kausaliteter på modernitetens betingelser: på flere planer, under flere synsvinkler, på kompleksitetens, kontingensens, komplementaritetens præmisser. Blandt polyfoniens forudsætninger er Dostojevskijs individuelle optik, hans specielle evne til at se alt i sammenhæng og vekselvirkning. Denne disposition karakteriserer Bachtin vel at mærke som »hans største styrke, men også hans største svaghed. Den gjorde ham blind og døv for yderst mange og væsentlige ting « (Dost, s. 37). Men også epoken og den menippæiske/grotesk realistiske genretradition var nødvendige forudsætninger:

»Den objektive kompleksitet, modsigelsesfuldheden og mangestemmigheden i Dostojevskijs epoke, plebejerens og den sociale lediggængers situation, den dybeste biografiske og indre delagtighed i livets objektive flerdimensionalitet og endelig evnen til at se verden i vekselvirkning og sameksistens - alt dette dannede den jordbund, af hvilken Dostojevskijs polyfone roman voksede frem.«(Dost, s. 37f.)

Man kan også, som jeg har gjort i min førnævnte introduktionsartikel (jvf. note 4), stille de omhandlede aspekter af polyfonien op efter 'størrelse'. Epokal forbindelse har de alle. Og deres konvergens i den polyfone roman er periodespecifik, må lokaliseres til forrige århundredes 'moderne gennembrud'. Det står til diskussion, hvad der skal til, for at man kan tale om en polyfon roman. Et forsigtigt skøn vil være, at den fuldt udfoldede polyfone roman forudsætter den nedennævnte konvergens af faktorer i et ganske særligt udsigelsesarrangement. Og at den historisk første gang - tilnærmelsesvis - blev realiseret i nogle af Dostojevskijs bedste romaner, f.eks. Forbrydelse og straf og Brфdrene Karamasov. Bachtins udredning af dens forudsætninger har imidlertid meget videre perspektiver: 
1) Det tostemmige ord: Denne form for ord, »stjernen « i Bachtins metalingvistik, er især fremherskende i brydningstider, hvor det enstemmige, direkte ords autoritet er svækket; hvor den konventionelle harmoni mellem ytring, kontekst og sprog ikke forefindes, hvor forudforståelsen mellem autor og adressat ikke længere er givet.

2) Dialogen: Den er fundamental i sproget og alt menneskeligt samvær. Moderniteten forvandler imidlertid tendentielt alle til ideologer og samfundslivet til en rasende diskussion, en 'stor dialog' (sammenhængende med den langsigtede tendens til demokrati).

3) Den polyfone roman: Dette er en subgenre af romanen, hvis fulde udfoldelse er (positivt/negativt) forbundet med kapitalismens specielt voldsomme gennembrud i det relativt tilbagestående russiske samfund.

4) Den menippaiske/grotesk realistiske littercere tradition og sarlige genrefelt: Det er denne litteraturhistoriske, genetiske synsvinkel, som placerer litteraturen i 'den store tid', som Bachtin i forlængelse af den russiske litteraturhistoriker Veselovskij betegner som historisk poetik.

5) Karnevallet som forvandlingens kulturform (synkretisk skuespilform, livsform): Her er hovedfeltet for Bachtins kultursemiotiske studier. I »Svar på et spørgsmål fra Novyj mir« siger han uden forbehold: »Litteraturen er en uopløselig del af kulturen, den kan ikke forstås uden for hele kulturens kontekstuelle helhed i en bestemt epoke. $\ll^{12}$ Specielt opfordrer han til, at litteraturvidenskaben fokuserer på de mægtige, dybe kulturstrømninger, der - snarere end rabalderet i litterære tidsskrifter - har bestemmende indflydelse på forfatternes skabende arbejde (DDO, s. 9).

Fra ytring til dialog til genre til litterær tradition til kulturform. Alle disse indbyrdes forbundne fænomener har blomstret i brydningstider. Bachtins billede af dem er tydeligvis konciperet ud fra hans egen moderne tid, brydningstiden par excellence. »Mangfoldigheden af fokuseringer. Tilnærmelsen af det fjerne uden at angive de mellemliggende led « $(D D O$, s. 272). Sådan karakteriserede Bachtin selv sit værk på godt og ondt i sine »Optegnelser 1970-71«. Det ovenstående antyder styrken ved Bachtins specielle evne til at bringe fænomener sammen, der konventionelt er adskilt $i$ tid og rum. Den moderne - $i$ afgørende henseender modernistiske - optik får nye ting frem i billedet af antikken og renæssancen. Omvendt giver Bachtins originale billede af romanens genesis i 
antikken og renæssancen væsentlige - endnu på langt nær ikke udnyttede muligheder for en uddybning, delvis revidering af synet på modernismen.

Jeg vender hermed tilbage til den autoritetens kunstneriske og ideologiske krise, som hele det ovennævnte problemkompleks udtrykker. I den polyfone roman er ingen enkelt stemme, heller ikke forfatterens, privilegeret bærer af værkets autoritative budskab. Dostojevskij, der har suspenderet sin forfatterautoritet, søger ganske vist som sit ultimative mål en andens autoritative ord. Men dette udgør en yderste grænse for hans kunstneriske univers - og er intetsteds realiseret (jf. Dost, s.195).

I »Ordet i romanen« konstaterer Bachtin under sin behandling af det autoritative ord, at det »aldrig har været en succes i romanen. Det er tilstrækkeligt at nævne Gogols og Dostojevskijs håbløse forsøg i denne henseende« (TDI, s. 344).

At Dostojevskijs bud på forfatterpositionen var et afgørende problem for Bachtin fremgår med al ønskelig tydelighed af den uafladelige kredsen om det i »Noter til en omarbejdelse af Dostojevskij-bogen « fra 1961. Polyfonien ses her som et svar på krisen både for forfatterens position, emotion og ord. Med afsæt i terminologien fra »Forfatter og helt i æstetisk aktivitet« noterer Bachtin, at det i Dostojevskijs romaner netop er vigtigt, at de enkelte positioner ikke smelter sammen, men bevarer udenforståenheden og det dermed forbundne synsoverskud. Det væsentlige er imidlertid Dostojevskijs brug af dette overskud, som aldrig tjener til objektivering og finalisering af den anden, men viser sig som kærlighed og vilje til forståelse.

Også skabertropen får en ny drejning, idet forfatter-skaberen sammenlignes med Prometheus, som skaber (eller genskaber) levende væsener, der er uafhængige og på lige fod med ham selv. Bachtin præciserer, at bogen kun vil befatte sig med litteraturhistoriske spørgsmål, for så vidt de er uomgængelige for karakteristikken af Dostojevskijs specifikke kunstneriske vision. Men i optegnelserne indsættes den polyfone roman klarere og mere koncentreret end i bogen selv i en moderne litteraturhistorisk kontekst:

$\gg$ Forfatterpositionens problem. Problemet med den tredje part i en dia$\log$. Forskellige løsninger på dette problem hos samtidige romanforfattere (Mauriac, Graham Greene og andre)./ Thomas Manns Doktor Faustus som en indirekte bekræftelse af min idé. Dostojevskijs indflydelse. Samtale med djævelen. Forfatter-kronikøren og hovedpersonen. Den komplekse forfatterposition (jvf. Manns breve). $\ll^{13}$

»Efter min bog (men uafhængigt af den) blev ideerne om polyfoni, dia$\log$, uafsluttelighed etc. udviklet vidt og bredt. Dette forklares af Dosto- 
jevskijs voksende indflydelse, men frem for alt naturligvis af de forandringer i virkeligheden selv, som Dostojevskij (i denne forstand profetisk) opnåede at åbenbare tidligere end de andre. $\ll^{14}$

Dostojevskij sættes altså ind i et epokalt tidehverv og en moderne litteraturhistorisk sammenhæng. En anden side af samme sag er parallelliseringen i den omarbejdede Dostojevskij-bog mellem den kunstneriske bevidsthed, der er impliceret i den polyfone roman, og den moderne videnskabelige bevidsthed:

»Det moderne menneskes videnskabelige bevidsthed har lært sig at orientere sig i de komplicerede betingelser, »sandsynlighedens univers « frembyder, uden at lade sig gå på af nogle »ubestemtheder «; i stedet tager det hensyn til og beregner det sandsynlige. For denne bevidsthed er Einsteins verden med dens mangfoldighed af beregningssystemer forlængst blevet noget tilvant. Men på den kunstneriske kundskabs område fortsætter man undertiden med at kræve den groveste, den mest primitive bestemthed, som åbenbart ikke kan være sand.«(Dost, s. 289f.)

\section{Lukács og Bachtin}

En sammenligning mellem Lukács og Bachtin kan både belyse udviklingsdynamikken - 'de indre modsigelser' - i Bachtins værk og forholdet til modernismen. En sådan sammenligning er foretaget før, og det er vanskeligt at komme uden om nogle tidligere bud. Michael Holquists meget generelle kontrastering af Lukács' hegelianisme med Bachtins modvilje mod den hegelske dialektik ${ }^{15}$ er i bedste fald lidet sigende, men dækker efter alt at dømme over et mere kompliceret forhold. Et signifikant bidrag, der har selve denne sammenligning som sit centrale emne, er ydet af Galin Tihanov. ${ }^{16}$

Artiklen »Bakhtin, Lukács and German Romanticism. The Case of Epic and Irony « forekommer mig perspektivrig. I redegørelsen for begges forhold til romantikken, med særligt henblik på Friedrich Schlegels romanteorier, er der gode idé- og kritikhistoriske pointer. Begrænsningerne, for ikke at sige farerne, i hans position er dog også åbenbare. Tihanov optræder som en generaliserende, klassificerende idéhistoriker på astronomisk afstand af sit emne. Lukács' og Bachtins positioner kan han mageligt reducere til en svingning mellem 'historisme' og 'essentialisme'. Lukács er mest til det første, Bachtin mest til det andet - og begge dele er tydeligvis Tihanov lige vederstyggelige.

Skulle man være i tvivl om Tihanovs reduktionisme, kan man læse artiklen »Reification and Dialogue. Aspects of the Theory of Culture and Society in 
Bakhtin and Lukács «, der på et ubestemmeligt abstraktionsniveau sammenligner Lukacs' Geschichte und Klassenbewußtsein (Historie og klassebevidsthed) fra 1923 med Bachtins romanessays fra 1930'erne. Lad os eksempelvis se, hvad han får ud af følgende interessante citat fra »Ordet i romanen«:

»alle heteroglossia-sprog, hvilket princip der end ligger under dem og gør hver af dem enestående, er specifikke synsvinkler på verden, former for begrebsliggørelse af verden i ord, specifikke verdensanskuelser, der hver kendetegnes af sine egne objekter, betydninger og værdier. Som sådanne kan de sidestilles med hinanden, supplerer hinanden gensidigt, modsiger hinanden og kan stilles dialogisk i forhold til hinanden. Som sådanne møder de hinanden og sameksisterer i virkelige menneskers bevidsthed - først og fremmest i den skabende bevidsthed hos mennesker, der skriver romaner. $\ll^{17}$

Af denne sprog- og romanteoretiske passage formår Tihanov at uddrage følgende:

»Bachtins idé om, at der kan være en menneskeart, der står over andre takket være den enkle kendsgerning, at vedkommende skriver romaner, er det ultimative udtryk for hans kvasi-romantiske tro på kunstens almagt. Litteratur, der er en sprogets skabning, synes at være i stand til at løse problemer, som ikke har deres oprindelse i sprog. $\ll^{18}$

Hvordan kan den ret indlysende antagelse, at (nogle) romanforfattere har sans for sprog- og kultursammenst ød, dog blive så grundigt forvansket som til en »tro på kunstens almagt « og så foragteligt forkastet? Hvorfor denne reduktionisme og arrogance? Tihanovs 'ideologikritiske' kunstfjendskab i det citerede afslører en radikal udenforståenhed i forhold til Bachtin, der her (som så ofte og i modstrid med Bachtins håbefulde formuleringer) langtfra er erkendelsesfremmende. Ved en lige så lidet relevant som elegant reference til Bachtins monologismekritik fra Dostojevskij-bogen viser Tihanov sin idiosynkrasi ved at søge at vende Bachtins ord mod ham selv. Passagens arrogance henter sin forudsatte autoritet i en quasi-de Man'sk tro på sprogets afmagt.

I Tihanovs afhandling Bakhtin and Lukács. The Theory of the Novel as Social Philosophy er det et fundamentalt anliggende at vise grænserne for Bachtins originalitet og stille spørgsmålstegn ved den indre sammenhæng i Bachtins opus. Tihanov går altså med i jagten på 'de indre modsigelser'. Hvilke han lægger vægt på, er allerede antydet i de omtalte artikler. I synet på Bachtins forhold til det moderne konvergerer Tihanov med den opfattelse, jeg søger at 
begrunde i denne artikel, ved at betragte hans værk som modsigelsesfulde reaktioner på moderniteten. Men hvorledes opfatter han så disse modsatrettede reaktioner?

Tihanov ser tydeligvis en uovervindelig modsætning mellem romanteoriernes hyldest til en mangesproget, kosmopolitisk verden, der gennem romanen frigør sig fra fortidens normer til fordel for det åbne nu - og på den anden side den førnævnte essentialisme, som Tihanov også betegner som fænomenologisk ahistorisme. At Bachtin i forskellige værker forholder sig positivt såvel til Goethe som til Rabelais opfatter han som en hyldest til gensidigt udelukkende samfundsidealer. Goethes gigantiske og komplicerede værk reducerer Tihanov nemt og bekvemt til et forsvar for liberale værdier i en traditionel borgerlig individualisme. Bachtins Rabelais-billede brændemærker Tihanov i tydelig forlængelse af Morson og Emerson - som en dubiøs dyrkelse af menneskeartens anonyme krop og som regressiv utopisme. ${ }^{19}$

Alle de nævnte positioner er ham tydeligvis lige modbydelige, og deres indbyrdes relationer be- eller rettere fordømmer han formallogisk. At tænke dem ud fra synsvinkler som relativitet, komplementaritet eller historicitet ligger ham fjernt. ${ }^{20}$ Hvordan man skulle komme til rette med fænomener som flerstemmige ytringer og dialog uden både at anlægge historiske og generelle synsvinkler, er mig en gåde. Og hvorfor skulle Rabelais og Goethe ud fra hvert sit historiske og æstetiske udgangspunkt ikke begge kunne repræsentere lige værdifulde - på nogle punkter alternative, gensidigt supplerende - positioner? Og med hvert sit interessante bud på en litterær gestaltning af tiden begge udgøre alternativer til Dostojevskij, der jo havde ringe sans for denne væsentlige dimension af tilværelsen? Ud fra Tihanovs formallogik er det uforklarligt, at en af hovedkilderne til Bachtins filosofiske tydning af karnevallet i Rabelaisbogen såmænd er Goethes Italienische Reise.

Hvis vi nu går fra Bachtin til forholdet mellem Lukács og ham, så er det én af Tihanovs hovedteser, at deres intellektuelle karrierer, uanset forskellene $i$ deres ydre status, slående fulgte ensartede veje. Foruden faglig udenforståenhed og historisk reduktionisme forekommer Tihanovs billede af kontinuitet og parallellitet mig at kunne forklares med, at han helt overvejende fokuserer på den unge Lukács og den modne Bachtin (1929-1941). ${ }^{21}$ Naturligvis er der elementer af kontinuitet mellem de to, herunder regulær påvirkning fra Lukács til Bachtin, som bl.a. vides at have læst Lukács' Romanens teori. Indflydelsen er indlysende, hvis man på et passende abstraktionsniveau sammenligner Romanens teori fra 1920 med Bachtins romanteoretiske essays fra 30'erne; med særligt eftertryk gælder det hans mest 'lukacsianske' ytring, foredraget »Epos og roman« fra 1941. 
Men tager man begges livsværk med - ja, tager man blot den unge Bachtin og den modne Lukács rimeligt i betragtning - så bliver billedet anderledes. Jeg vil i korthed søge at sandsynliggøre, at man med nok så god begrundelse kan tale om Lukács' og Bachtins omvendte, modsatrettede udviklingsveje. Det er rigtigt at man - på et bestemt abstraktionsniveau og med bortseen fra væsentlige allestedsnærværende forskelle - kan finde beslægtede positioner hos Lukács og Bachtin. Men ikke på samme tid. Jeg vil dermed hævde, at deres indbyrdes forhold beskriver en bytten position, en krydsbevagelse eller sælsom omvendt proportionalitet.

I Romanens teori indtager Lukács på mange måder et moderne eller ligefrem modernistisk standpunkt. Værket er tegnet over en forfaldsfigur, der nok med veneration ser tilbage til en forladt harmonitilstand, men også er illusionsløs, da den beskrevne udvikling betragtes som irreversibel. Lukács ser tilbage på eposet med megen sympati, som et adækvat udtryk for en i sig selv hvilende, sluttet, organisk tilstand. Dette er imidlertid udgangspunkt for en modernitetsbestemmelse i forlængelse af Nietzsches. Der er ingen vej tilbage. I forhold til romanen anes Lukács' senere sympatier for den 'klassisk' fortællende, realistiske roman i hans positive karakteristik af Henrik Pontoppidans Lykke-Per. Ellers er det slående indtryk et helt andet romansyn og næsten konsekvent den modsatte vurdering af romanforfattere end senere.

Romanen som genre karakteriseres af det fleksible, processuelle: »Således fremtræder romanen, i modsætning til andre digtarter, der eksisterer hvilende i en færdig form, som noget tilblivende, som en proces. $\ll^{22}$ Den er ikke, som epopéen, et »homogent-organisk kontinuum«, men et »heterogent-kontingent diskretum«. Den præges af subjektivitetens selverkendelse, og dermed selvophævelse, af romantikkens æstetikere (Lukács hentyder især til Friedrich Schlegel) kaldet ironi: »Denne ironi er det brudfyldtes selvkorrektur: de inadækvate relationer kan forvandle sig til en fantastisk og velordnet række af misforståelser og gåen forbi hinanden, hvor alt bliver set fra mange sider [...]« (Roman, s. 62).

I kapitlet »Romanens historiefilosofiske betingethed og betydning « er Lukács’ formuleringer særligt udpræget nietzscheansk-modernistiske og Bachtinforegribende. »Romanen er den gudsforladte verdens epopé; romanheltens psykologi er det dæmoniske« (Roman, s. 74). »Digterens ironi er de gudløse tiders negative mystik « (Roman, s. 76). Vi finder skabertropen i fuld udfoldelse. I hvilket omfang er romanhelten fri over for forfatteren? spørger Lukács og svarer med Hebbel: »»I det omfang, som mennesket er frit i sit forhold til Gud.««Helten kan i lucifersk trods realisere sig selv, og »Det normative menneske har tilkæmpet sig friheden over for Gud« (Roman, s.76). Men »hvad der [...] er frihedens egentlige væsen, forbliver uudsigeligt« (Roman, s.77). Til 
skabertropen slutter sig således den ærke-modernistiske tavshedstematik: Lukács ser romanen som en nødvendig »omvej over sproget til tavsheden« (Roman, s. 77).

Med dette romansyn følger en romanforfatternes kanon, hvor senere helte optræder som skurke og omvendt. Blandt heltene er Flaubert - som Lukács siden skulle tage så ofte og energisk afstand fra som en af de hovedansvarlige for romanens udarten i naturalisme og modernisme. En hovedskurk er den senere superhelt Tolstoj. Og karakteristikken minder vel at mærke slående om den, vi finder i Bachtins Dostojevskij-bog (jf. f.eks. Dost, s. 77ff.). Tolstoj kritiseres for sit illusionære, mislykkede forsøg på at skrive epopéer i en tid, der historisk har taget grunden væk under den; derfor »måtte hans sindelag for epopéen lande i en problematisk romanform« (Roman, s. 127). Denne fortidsvendthed viser sig i Tolstojs bestandige fokuseren på døden. Om de bekendte åbenbaringer af pludseligt klarsyn i Tolstojs romaner skriver Lukács, at »det er dødens store $\varnothing$ jeblikke, der leverer denne afgørende salighed « (Roman, s. 130). Karakteristikken svarer nøje til Bachtins i Dostojevskij-bogen. Konkluderende placerer Lukács Tolstoj som »afslutningen på den europæiske romantik« (Roman, s. 132). Hans anelser om en ny verdensepoke »forblev polemiske, længselsfulde og abstrakte« (Roman, s. 133).

Det moderne alternativ personificeres af ingen anden end Dostojevskij:

»Først i Dostojevskijs værker bliver denne nye verden, fjernt fra enhver kamp mod det bestående, nedtegnet som en enkel, set virkelighed. Derfor står han, og står hans form, uden for disse betragtninger: Dostojevskij skrev ingen romaner, og det gestaltende sindelag, der bliver synligt i hans værker, har hverken bejaende eller benægtende noget at gøre med det nittende århundredes romantik og med den mangfoldige, ligeledes romantiske reaktion imod den. Han tilhører den ny verden.« (Roman, s. 133)

Ren Bachtin. Sammenlign eksempelvis med denne passage fra Dostojevskijbogen:

»Hverken helten eller ideen eller selve det polyfone princip for opbygning af helheden rummes inden for de genremæssige og plot-kompositionelle former, som kendetegner den biografiske, social-psykologiske roman, hverdags- og familieromanen, dvs. inden for de former, som var fremherskende på Dostojevskijs tid og udvikledes af samtidige forfattere til ham som Turgenjev, Gontjarov, Tolstoj.«(Dost, s. 109) 
I Romanens teori hævder Lukács således, hvad der i alt væsentligt må betegnes som en modernistisk opfattelse af den litterære situation og romanens rolle heri: romanen svarer til en situation, hvor de fælles værdier er i opløsning og autoriteten i krise. Vurderingen af Tolstoj er først og fremmest negativ på grund af hans fortidsvendthed og fors $ø g$ på at skrive epopéer, en form, moderniteten har taget grunden væk under. Vurderingen af Dostojevskij, der repræsenterer en ny epokes litterære form, er derimod skyhøj. Konceptionen svarer i rigtig mange grundlæggende henseender til Bachtins opfattelser om samme emner fra og med hans kopernikanske revolution i 1929.

Frem til dette tidspunkt hævder den unge Bachtin derimod en traditionel romanæstetik - baseret på fortællingen, distancen og den autoritet, hvormed forfatteren formår at hævde sine værdier og afrunde billedet af helten. Ganske vist gør autor-itetens krise sig stadigt stærkere gældende, og en af hovedskurkene i denne opløsningsproces er Dostojevskij. Konceptionen svarer i adskillige væsentlige henseender til den modne Lukács' position fra og med 1930'ernes essays om realisme og den historiske roman - og medfølgende afstandtagen fra naturalisme og modernisme.

En krydsfigur, en kiastisk bytten positioner: Den unge Bachtin svarer til den modne Lukács - den unge Lukács svarer til den modne Bachtin. Den første position er anti-, den sidste pro-modernistisk.

\section{Den usynlige autor og tavshedens litteraturhistorie}

Afslutningsvis skal jeg skitsere Bachtins holdning til de ovennævnte temaer i sidste fase af hans forfatterskab. De forbløffende idérige 1970'er-optegnelser rummer blandt meget andet nogle af hans mest spændende betragtninger over disse problemer: forfatterpositionen i den moderne roman og en indplacering af Dostojevskij og den polyfone roman i modernismens historie.

Vi kan starte i Bachtins overvejelser over det førnævnte ærke-tema i modernismen, nemlig tavsheden. Den intense optagethed af (ikke-)fænomener som nulpunkt, tavshed, intethed, negation, fravær etc. er formentlig et af modernismens og modernitetstænkningens mest slående fællestræk. Heidegger (som Bachtin flere gange henviser til i sine sene optegnelser) ser i Sein und Zeit tavsheden som en oprindelig modus af talen, ovenikøbet én, der forudsætter en »egentlig og rig åbenhed $\ll{ }^{23}$ I samme baner tænker Bachtin. I »Optegnelser 1970-71 « skelner han mellem stilhed og tavshed:

»Stilhed og lyd. Fornemmelsen af en lyd (på baggrund af stilheden). Stilhed og tavshed (mangel på ord). Pausen og ordets begyndelse. At bryde 
stilheden gennem lyden er mekanisk og fysiologisk (som betingelse for fornemmelsen); at bryde tavsheden gennem ordet er personalistisk og meningsfuldt: dette er en helt anden verden. I stilheden lyder intet (eller noget lyder ikke) - $\mathrm{i}$ tavsheden taler ingen (eller nogen taler ikke). Tavsheden er alene mulig i menneskets verden (og kun for mennesket). Naturligvis er både stilheden og tavsheden altid relative. [...]/ Tavsheden en tolket lyd (ord) - og pauser udgør en særlig logosfære, en enhedslig og sammenhængende struktur, en åben totalitet (umulig at fuldbyrde).« (DDO, s. 262)

En senere betragtning skitserer en tavshedens litteraturhistorie, idet tavsheden ses som en af udvejene i en langvarig litterær (autoritetsmæssig, identitetsmæssig, 'sproglig') krise:

»At søge efter sit eget ord er i sig selv ikke en søgen efter sit eget ord, men efter et ord som er større end mig selv; det er en stræben efter at opgive sine egne ord, ved hvis hjælp intet væsentligt kan siges. Selv kan jeg kun være en rolleperson, ikke en primær forfatter. Forfatterens søgen efter sit eget ord er i hovedsagen en søgen efter en genre og en stil, en søgen efter en forfatterposition. Dette er i dag litteraturens vanskeligste problem, som får mange til at opgive romangenren og erstatte den med montage af dokumenter, beskrivelser af ting, lettrisme, og som til en vis grad også er ophav til den absurde litteratur. Alt dette kan man i en vis forstand bestemme som forskellige former for tavshed. Denne søgen førte Dostojevskij til skabelse af den polyfone roman. For den monologiske roman fandt han intet ord. Tolstojs parallelle vej til de folkelige beretninger (primitivismen), til at indføje ciater fra evangelierne (i de sidste dele). En anden vej er at tvinge verden til at tale og lytte til verdens egne ord (Heidegger).«(DDO, s. 267)

Det er et grundtræk ved det moderne, at den egentlige primær-autor netop ikke kan træde autor-itativt frem, han er usynlig og tavs: »Den primære forfatters ord kan ikke være hans eget ord. [...] Derfor klæder den primære forfatter sig i tavshed. Men denne tavshed kan antage forskellige udtryksformer, forskellige former for reduceret latter (ironi), allegori osv. $\ll^{24} »$ Ironi har gennemtrængt alle sprog i moderne tider (især fransk)«, hævder han andetsteds i optegnelserne. »Det moderne menneske proklamerer ikke; det taler. Dvs. det taler med forbehold. Proklamatoriske genrer er hovedsageligt blevet bevaret som parodiske og halvparodiske byggesten for romanen. $\ll^{25}$ 
Disse epokal-litteraturhistoriske betragtninger går hånd i hånd med en mere almen-teoretisk indkredsning af autor-instansens usynlighed i praktisk talt alle de sene tekster. En af de allerseneste (»Mod en metodologi for de humanistiske videnskaber «) formulerer problemstilingen således i endnu en variation over skabertropen:

»Et værks forfatter er kun til stede i værkets helhed og findes ikke i et enkelt adskilt moment af det, og mindst af alt i dets indhold, adskilt fra helheden. Han befinder sig i det uadskillelige moment i værket, hvor indholdet og formen uopløseligt forenes, og mest af alt fornemmer vi hans nærvær i formen.[...] Ophavsmanden-forfatteren kan ikke skabes i den sfære, hvor han selv er skaberen. Der er tale om natura naturans [den skabende natur] og ikke natura naturata [den skabte natur]. Vi kan kun se skaberen i hans værk og absolut ikke uden for det.« (DDO, s. 270)

Netop på grund af skabertropen - analogien mellem autor-skaberen og Gud aner vi en forbindelse mellem Bachtins og Nietzsches billeder af moderniteten. Ligesom den guddommelige er den litterære autor-itet død eller i det mindste henvist til at være deus absconditus, til usynlighed og tavshed. Det skyldes et tab af positivt proklamerbare og fælles bindende værdier, af en selvfølgelig, uanfægtelig autoritet.

I sine forskellige betragtninger over autor-iteten og dens krise har Bachtin både bidraget til en litteraturteoretisk belysning af autor-instansen og til modernismens historie. I forhold til Dostojevskij og den polyfone roman har jeg nu henledt opmærksomheden på de afgørende udvidelser af det epokal-litteraturhistoriske synsfelt, som forekommer mig temmeligt oversete. Bachtins samlede forfatterskab rummer et vidt spektrum af meget forskellige synsvinkler på den litterære polyfoni. Han betoner Dostojevskijs originale indsats kraftigt i 1929-bogen, men det er også et vigtigt synspunkt i andenudgaven. Desuden placerer han den polyfone roman i en historisk poetik-sammenhæng (jvf. titelskiftet fra Problemer i Dostojevskijs vark til Problemer i Dostojevskijs poetik) ved at afdække dens rødder i en ældgammel karnevalsk-menippæisk kultur- og genretradition. Det forhindrer som bekendt ikke, at han i metalingvistik-kapitlet tillige anskuer den polyfone roman som et privilegeret udtryk for selve sprogets iboende dialogicitet. Men hertil kommer den væsentlige dimension, jeg her har søgt at fremdrage, nemlig en epokal-litteraturhistorisk forståelse, der placerer den polyfone roman som et af flere særtilfælde og 'løsninger' i modernismens problematiske historie. 
På ovenstående baggrund kan jeg bekræfte Holquist og Clarks tese, at autorbegrebet er et nøglebegreb og skabertropen en mestertrope i Bachtins forfatterskab. Jeg kan tilføje, at autorbegrebet (allerede skitseret i Mod en handlingens filosofi og fuldt udfoldet fra »Forfatter og helt i æstetisk aktivitet«) optræder med en terminologisk konsekvens, der er sjælden hos Bachtin. Og dette har gyldighed ikke blot for de filosofiske første og sidste faser, men for alle de mellemliggende værker.

Samtidig ser jeg den intellektuelle kolbøtte med Dostojevskij-bogen og de stadige efterfølgende forskydninger i Bachtins forhold til autorbegrebet som en nøgle til de indre modsætninger i hans værk. Disse underspilles ofte af Holquist. Modsætningerne må tages alvorligt. De udgør det uundværlige udgangspunkt for en forståelse af Bachtins relation til modernismen og af forholdet mellem ham og Lukács. Jeg har imidlertid søgt at argumentere for et alternativ til de idiosynkratiske og reduktionistiske opfattelser, der bringes til torvs af modsigelsesjægerne.

\section{Noter}

1. Ved udgivelsen af Rabelais and His World, Cambridge, Mass. 1968, og de franske oversættelser af Dostojevskij-bogen 1970, specielt La poétique de Dostoievski, Paris 1970, og det tyske udvalg af begge i Literatur und Karneval. Zur Romantheorie und Lachkultur, München 1969, m.v.

2. Med væsentligste udgangspunkt i antologien The Dialogic Imagination. Four Essays by M.M. Bakhtin, Edited by Michael Holquist, Austin 1981 [herefter TDI].

3. In: Comparative Literature, 1994, Vol. 46, Number 4, s. 321-345.

4. In: Poetik, 4. årg., nr. 1, s. 3-44. Genoptrykt i antol. Litteraturvidenskab, Roskilde 1974, s. 107-154.

5. Comparative Literature, 1994, Vol. 46, Number 4, s. 331.

6. Rabelais och skrattets historia, Gråbo 1991, s. 55.

7. Toward a Philosophy of the Act, Austin 1993. Jvf. den nøjere karakteristisk af de tidlige værker i Bruhn og Lundquists artikel i dette nummer af $K \& K$.

8. Art and Answerability. Early Philosophical Essays by M.M. Bakhtin, Austin 1990, herefter $A A A$, s. 23. I de nærmeste passager trækker jeg i øvrigt på Bachtin-afsnittet i min doktorafhandling Metamorfoser i Mellemtiden. Studier i Svend åge Madsens forfatterskab 1962-1986, København 1997.

9. Clark, Katerina, og Holquist, Michael: Mikhail Bakhtin, Cambridge, Mass. 1984, s. 248.

10. Op. cit., s. 80.

11. Dostojevskijs poetik, Gråbo 1991, herefter Dost, s. 65.

12. Det dialogiska ordet, Gråbo 1991, herefter DDO, s. 8.

13. Problems of Dostoevsky's Poetics, Minneapolis 1984, s. 284.

14. Op. cit., s. 285.

15. In: Dialogism. Bakhtin and his World, London og New York 1991, s. $73 \mathrm{ff}$.

16. a)«Reification and Dialogue. Aspects of the Theory of Culture and Society in 
Bakhtin and Lukács«, in: Bakhtin and the Humanities. Proceedings of the International Conference in Ljubljana, October 19-21, 1995, Ljubljana 1997, herefter $R A D$

b) »Bakhtin, Lukács and German Romanticism: The Case of Epic and Irony«, in: Adlam et al. (red.): Face to Face. Bakhtin in Russia and the West, Sheffield 1997.

c) Bakhtin and Lukács: The Theory of the Novel as Social Philosophy, ph.d.-afhandling, Oxford, Jesus College, Trinity Term 1997. Upubliceret, men via British Thesis Service tilgængelig for lån - på mikrofilm.

Jeg takker Jørgen Bruhn for henvisninger.

17. TDI, s. 291f. Tihanov har forresten fejl i citatet.

18. $R A D$, s. 88. Passagen gentages ordret i afhandlingen, s. 89.

19. Jf. bl.a. sammenfatningen $\mathrm{i} »$ Longer Abstract«, s. 8f. (uden sidetal i afhandlingen).

20. Bortset fra at Tihanov egentlig netop praktiserer en håndfast båsende, reduktionistisk historisme.

21. Ikke mindst i forhold til litteraturen. Den modne Lukács fremtræder hos Tihanov især på et højt abstraktionsniveau som hegeliansk filosof.

22. Romanens teori, Århus 1994, herefter Roman, s. 59.

23. Sein und Zeit, Tübingen 1993, s. 165.

24. Speech Genres and Other Late Essays, Austin 1986, s. $148 f$.

25. Op. cit., s. 132. 
